Boletín de la Sociedad Geológica Mexicana

VOLUMEN 65, NÚM. 1, 2013, P. 157-167

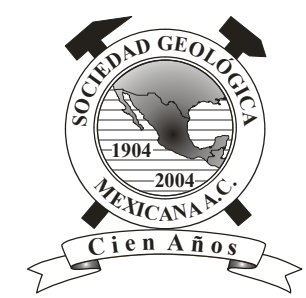

\title{
Effects of regional subsidence and earthquakes on architectural monuments in Mexico City
}

\author{
Efraín Ovando-Shelley ${ }^{1, *}$, Alexandra Ossa ${ }^{1}$, Enrique Santoyo ${ }^{2}$ \\ ${ }^{1}$ Instituto de Ingeniería, Universidad Nacional Autónoma de México, Circuito Escolar sn, Ciudad Universitaria, C.P. 04510, México \\ D.F., Mexico. \\ ${ }^{2}$ TGC Geotecnia S. A. de C. V., Adolfo Prieto \#1238, Col. Del Valle, Del. Benito Juárez, México D.F., 03100, Mexico. \\ *eovs@pumas.ii.unam.mx
}

\begin{abstract}
Mexico City is mostly located over extremely soft lacustrine clays that have been undergoing a consolidation process due to the exploitation of the aquifers underlying these soils. Therefore, the city has been sinking and will continue to do so in the foreseeable future; resulting differential settlements have constantly damaged most of the city's architectural heritage. México City is located within a high seismicity zone. Earthquakes have also damaged the city's architectural treasures and will continue to be threatened by them in the future. In this paper it is described the way in which these two hazards have affected monuments in the past, and at the ways in which they may as well be combined in the future to pose further threats. In order to do that, it is considered the change of the properties of the subsoil as a result of the futures changes of pore pressures within the clays, and of the resulting effective stress increments in the seismic response of the soft lacustrine clay deposits.
\end{abstract}

Keywords: Historic monuments, regional subsidence, earthquakes.

\section{Resumen}

Gran parte de la ciudad de México se ubica sobre depósitos de arcillas de origen lacustre de alta compresibilidad las cuales se han consolidado por efecto de la explotación de sus acuiferos. Por tal motivo, la ciudad está hundiéndose de manera diferencial y continuará haciéndolo en el futuro; los diferenciales de hundimiento han dañado y continuarán dañando a su patrimonio arquitectónico. Por otro lado, la ciudad de México se localiza en una zona de alta sismicidad. Los temblores que la asuelan han dañado los tesoros arquitectónicos de la ciudad y continuarán dañándolos en el futuro. En este documento se describe la forma en que estas dos amenazas han afectado, en el pasado, a dicho patrimonio; también se discute cómo se pueden combinar para generar más daño. Para ello se toma en cuenta el cambio de las propiedades del subsuelo debido a la evolución futura de la presión de poro y la de los incrementos de esfuerzos efectivos resultantes en la respuesta sísmica de los depósitos arcillosos de antigua zona lacustre.

Palabras clave: Monumentos históricos, subsidencia regional, terremotos. 


\section{Introduction}

Modern large cities are frequently exposed to natural and man-made risks which affect many aspects of urban development. Political, social, economic, geographical, morphological, geological conditions and others, determine the way in which hazards can be faced in practice, and authorities will generally seek means for eliminating or mitigating these risks and their effects. These conditions combine in various ways to preclude or limit the effectiveness of public policies for hazard management.

According to Geotechnical Engineering, the way in which two of these risks havecompromised in the past the integrity of architectonic monuments in Mexico City has been investigated. Earthquakes and regional subsidence, as well as the way in which they may combine in the future, are considered to endanger seriously the permanence of the architectural heritage of the central part of the city.

\section{Background}

As is cited in Cerca et al. (2012) the Aztec city of Mexico-Tenochtitlan was founded in the year 1325 on a marshy isle in the middle of Lake Texcoco. This lake, the lowest portion of a closed basin surrounded by volcanic mountain ranges, overlies a series of clays and clayey silts formed by the chemical degradation of pyroclastic materials driven into by water flows and winds. These clays are notorious for their extremely high water contents, their considerably low shear strength and their remarkably large compressibility.

Aztec constructions were concentrated in and around the religious precinct that constituted the core of the old city. Temples on extremely heavy earthen pyramidal structures, clad with stone and colored stucco, dominated the skyline. Built directly on very soft lacustrine clays, these pyramids underwent extremely large settlements and were repaired periodically or, as was the custom in Mid-America, were substituted by newer pyramids built directly over the older ones.

The Spaniards conquered and razed Mexico-Tenochtitlan in 1521, and a new city was built literally on top of the older one. Spanish masons adapted and used foundation techniques devised by the Aztecs, like short stakes with flat stone heads; they also imported European constructive techniques and tried to adapt them to the difficult subsoil conditions, not always successfully. Most of the Spanish buildings erected in the $16^{\text {th }}$ century underwent extremely large settlements and have almost disappeared, in many cases "swallowed" by the ground. In order to limit and mitigate the problems caused by differential settlements induced by the self weight of structures and in lieu of other technological resources, the height of most structures was limited to two stories, to avoid their colapse, as referred by Cervantes de Salazar in 1550 (Cervantes de Salazar,
1978), who established this limit to avoid earthquake related damage (this is probably the first rule for building earthquake resistant structures in the Americas). Foreign voyagers that visited the city in 1596, wrote that "everything sank or tilted", as quoted by Musset (1992).

In the construction of manors, palaces, civic buildings or the larger religious ones, such as convents and churches, engineers used ingenuity, patience and great ammounts of money. Innovative foundation solutions were often tried and tested, as in the Metropolitan Cathedral, where a masonry platform, actually a foundation raft of 60 by 120 $\mathrm{m}$ approximately, was tried for the first time in the city in 1573. These heavier structures were subject of recurrent interventions to correct structural damage caused by differential settlements induced by the consolidation of the underlying clays, a result of the overburden on the soil by the structures themselves. In many occasions, foundations were altered, and underpinning of the larger conventual churches and cloisters was not rare. Overall, the approach for building foundations and foundation systems was empirical, and it was late in the $19^{\text {th }}$ century when attempts to rationalize these techniques were first introduced.

Upon the destruction of the pre-Hispanic system of levees and embankments that regulated the water in the lake system, the city flooded periodically. The most severe flood took place in the early $17^{\text {th }}$ century, when the city was covered by water for five years (1629-1634) and the older structures became further damaged. After this event, the resolution of the authorities to eliminate the threat by drying the lake was strengthened. Floods were mitigated with a trench excavated in the mountains of the northern portion of the basin, in order to divert one of the rivers that reached the lake. After the completion of the monumental trench in the $18^{\text {th }}$ century, no further drainage works were undertaken until the late $19^{\text {th }}$ and the early $20^{\text {th }}$ centuries. The sketch maps in Figure 1 illustrate the evolution of the lake system, and the way in which drainage and land reclamation for urban expansion produced the gradual shrinking of the lake, which is nowadays practically nonexistent.

\section{Geotechnical conditions in central Mexico City}

Most of the soil under Mexico City consists of low strength, highly compressible lacustrine clays and allophanes. As quoted by Cerca et al. (2012), in most of the area formerly occupied by the lakes, main soil formations are ordered in a sequence of soft clay strata interspersed with lenses and layers of harder clayey silts with sands. As seen in the stratigraphical cross-section of Figure 2, the main soil strata are: a) artificial fills, mainly archaeological debris, as the uppermost materials; b) the original surface crust of dried low plasticity silty clays; c) the upper clay formation having the most compressible soils, as seen in Figure 2, which is interspersed with six thin sand layers d) the first hard layer that appears at an average depth of 


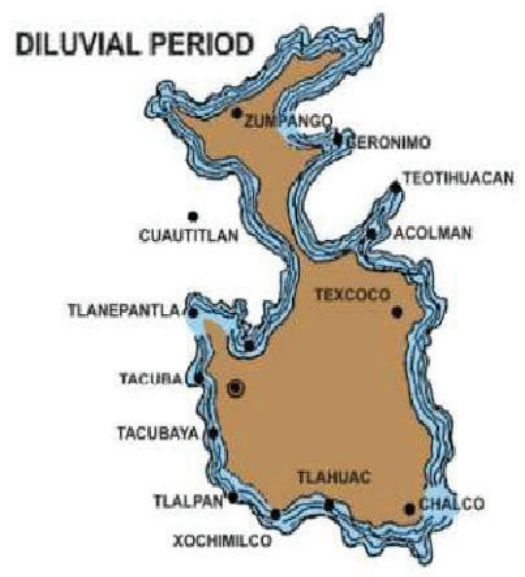

\section{EARLY 19th CENTURY}
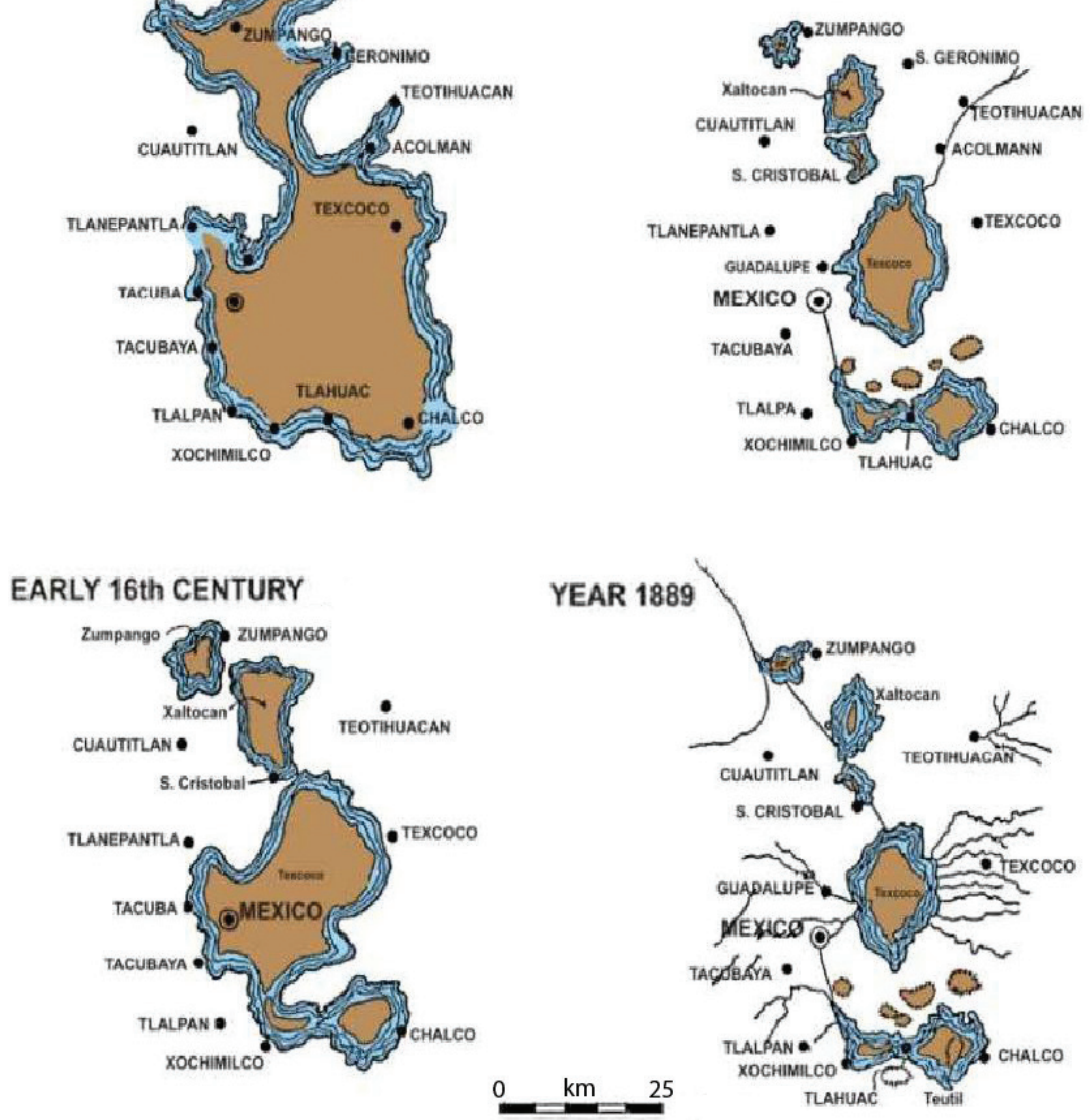

Figure 1. Evolution of the lake system.

about $40 \mathrm{~m}$, formed by sands, gravely sands and thin lenses of softer silty clays; e) the second clay formation, about $10 \mathrm{~m}$ thick, as shown in Figure 2; and f) the so called deep deposits -very consistent silts and sandy silts interspersed with hard clays- appear at the base of the stratigraphical column (50 $\mathrm{m}$ deep or so). This information was also reported by the main author in Cerca et al. (2012) work in which he is coauthor. .

\section{Regional subsidence}

Regional subsidence is not an exclusive problem of Mexico City. It affects other cities where water is extracted from the subsoil. Two of the most alarming cases are Venice and Bangkok, where the safety of architectonic monuments has been of critical importance in devising solutions to the problem.

Other cities in México are now suffering from the effects of regional subsidence, but the case of the capital is greater in both size and complexity than any other.

Subsiding ground has probably affected Mexico City for more than 150 years. The results of levelings performed in the city in 1860,1870 and 1888 , led to the recognition early in the $20^{\text {th }}$ century that the city was actually sinking, but engineers and scientists of the time were unable to relate regional subsidence to extraction of water from the subsoil (Cerca et al., 2012).

Initially, artesian water was drawn from relatively shallow wells; water was later pumped from deeper ones as demand increased in the second half of the 19th century. With Terzaghi's Consolidation Theory as a basis, the relationship between population growth, amount of water extracted from the aquifer and subsidence rates, was established by the groundbreaking work of Carrillo (1948), later continued by Marsal and Mazari (1959). Data collected by Tamez (1992) show that from 1900 to 1920 the settlement rate in downtown Mexico City was $3 \mathrm{~cm} /$ year; by the $1940 \mathrm{~s}$ the rate increased to $13 \mathrm{~cm} /$ year and in the early '50s it reached $26 \mathrm{~cm} /$ year. Wells in downtown Mexico City were banned and settlement rates decreased to $5 \mathrm{~cm} /$ year. In the late ' 70 s and early ' 80 s new wells became operational in the outskirts, mainly near the hills surrounding the city in the north and south. Settlement rates increased again, and in central Mexico City they now amount 7 to $10 \mathrm{~cm} /$ year, but at some sites near the newer wells they exceed $30 \mathrm{~cm} /$ year 


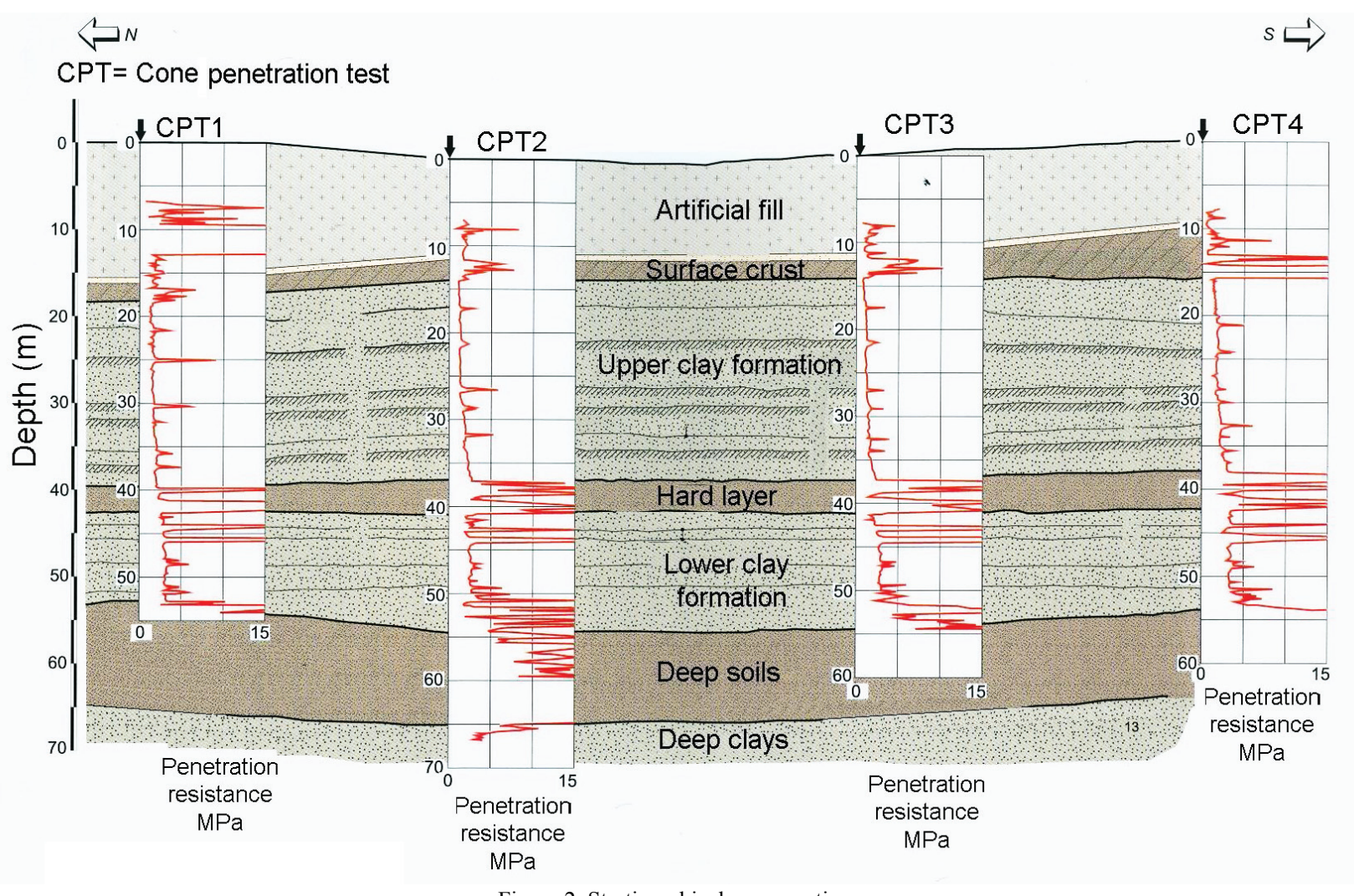

Figure 2. Stratigraphical cross-section.

(Mazari, 1996). There are zones in the outskirts, towards the edges of the former lake bed, where the ground settles 40 to $60 \mathrm{~cm} /$ year (Santoyo-Villa et al., 2005). The total subsidence over the last 100 years regarding to a reference point outside the lake zone now exceeds $10 \mathrm{~m}$ in some areas.

Surface settlements are the result of changes that occur within the soil mass due to the consolidation process triggered by the depletion of pore pressures as a consequence of the exploitation of the aquifers that underlie the soft clays. Most significantly, effective stress increments within the clay mass will modify stress and stress path dependent parameters like shear strength, compressibility and permeability. Consolidation of the lacustrine clays affects the totality of the former lake zone. As regional consolidation progresses, the clays gain strength and become stiffer; they also lose compressibility and permeability.

Field and laboratory data collected over the last few decades have been used to document the way in which mechanical and index properties change. The graph in Figure 3, for example, shows one dimensional compression curve obtained from testing of three samples retrieved from the same site at three different dates. As observed, initial void ratios have reduced gradually over the years and apparent preconsolidation pressures have decreased; the three samples exhibit approximately the same virgin consolidation line. Results of Cone Penetration Tests (CPT) show increasing point penetration resistance over a 14

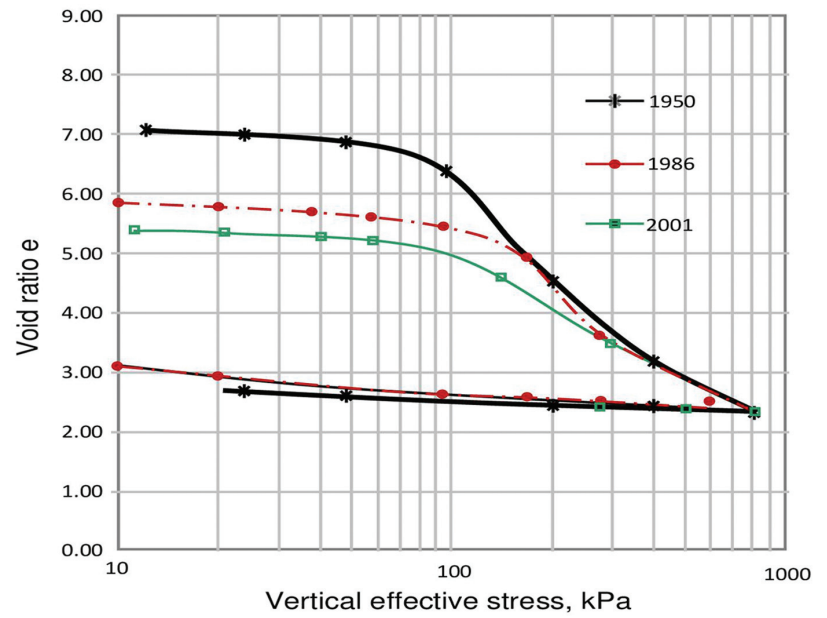

Figure 3. One dimensional compression curves obtained from oedometric tests performed on samples retrieved from the same site and the same stratum at different dates. (Ovando-Shelley et al., 2007).

year period, as illustrated in Figure 4. The CPT profiles in that figure also show changes in the thickness of the upper clay formation, of about $100 \mathrm{~cm}$ between 1986 and 2000 . Compression of the upper clay formation contributes with approximately 50 to $60 \%$ of total settlements measured in the central part of the city.

The estimation of the magnitude and distribution of future settlements in the city is important for several 


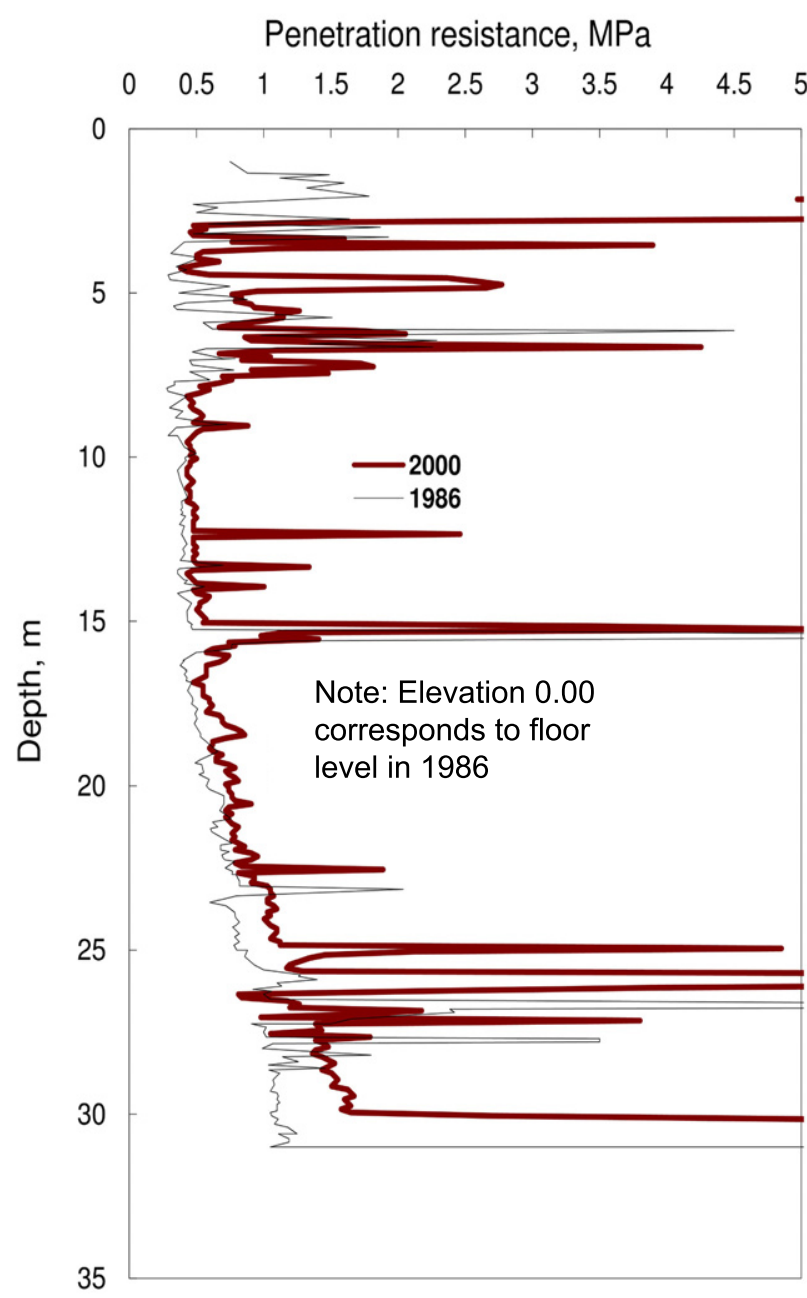

Figure 4. Results of CPT tests performed at the same site and two different dates (Ovando-Shelley et al., 2007).

practical applications including problems regarding to the conservation of architectural monuments.

The calculation of future settlements should consider the variability of soil properties, stress conditions and stress histories in the clay masses, as well as their evolution with time. These factors have been previously studied in other investigations (Ovando-Shelley et al., 2003, 2007; OvandoShelley and Ossa 2004). The evolution of pore pressures in the coming years was estimated assuming that the clayey soils are elastic-viscous-plastic materials, integrating the following set of differential equations (Yin and Graham 1994, 1996):

$$
\begin{gathered}
c_{v e} \frac{\partial^{2} u}{\partial z^{2}}=\frac{\partial u}{\partial t}-\frac{1}{m_{v e}} g\left(u, \varepsilon_{z}\right) \\
\frac{\partial \varepsilon_{z}}{\partial t}=-m_{v e} \frac{\partial u}{\partial t}+g\left(u, \varepsilon_{z}\right) \\
g\left(u, \varepsilon_{z}\right)=\frac{\psi / v_{0}}{t_{0}} \exp \left[-\left(\varepsilon_{z}-\varepsilon_{z 0}^{v p}\right) \frac{v_{0}}{\psi}\right]\left(\frac{\sigma_{z}^{\prime}}{\sigma_{z 0}^{\prime}}\right)^{\frac{\lambda}{\psi}}
\end{gathered}
$$

where $c_{v e}$ is a consolidation coefficient associated with elastic deformations, equal to $\mathrm{k} /\left(m_{v e} \gamma_{w}\right) ; \gamma_{w}$ is the unit weight of water, $k$ is the soil's permeability and $m_{v e}$ is the volumetric compressibility along the elastic portion of the one dimensional stress-strain curve, equal to $\partial \varepsilon_{z}^{e} / \partial \sigma_{z}^{\prime}=(\kappa /$ $\left.v_{0}\right) /\left(\sigma^{\prime} z\right) ; \psi / v_{0}=C_{\alpha \varepsilon} / 2.3$, where $C_{\alpha \varepsilon}$ is the slope along the compressibility curve in log time versus strain; finally $\lambda / v_{0}$ is the slope of a reference one dimensional stress-strain curve.

Equations 1 to 3 were applied to 21 sites in the central part of the city integrating them numerically with a finite difference algorithm. The Mexico City clay deposits were modeled considering that the two main clay strata are confined by permeable layers strata undergoing independent consolidation processes (Ovando and Ossa, 2004). Initial conditions were specified from piezometric readings obtained at nearby locations. Conditions at the boundaries were specified from pore pressure depletion rates at the permeable layers that confine the clays. Relevant properties for modelling the consolidation process were estimated from the results of CPT soundings performed in each site (compressibilities and permeabilities, as well as thicknesses of each substratum); during the integration process, these properties were updated after each time interval.

The resulting isochrone curves were used to obtain effective stress changes which were then used to calculate settlements in each of the studied sites. Deformations (compressions) of the two main clay strata were added to produce equal settlement contours at different dates. The map in Figure 5, for example, provides settlement contours estimated for the year 2075. The area covered includes the city's main square, the Metropolitan Cathedral, the National Palace and many other important architectonic monuments. As seen in the map, the calculated settlements are not uniform; differential settlements that will accumulate in the future are considerably large and will endanger several buildings of the zone.

Two of the most distinctive buildings shown in the map, the Metropolitan Cathedral and the National Palace, have been subjected to interventions in order to avoid or mitigate damage induced by differential settlements. The former was underpinned partially with point-bearing piles and the latter was first underexcavated to correct excessive differential settlements and afterwards its subsoil was selectively hardened so that it could attain a more uniform distribution of compressibilities.

In regard to these two monuments, contours shown in Figure 5 represent one of the possible scenarios that could have affected them, had the interventions not taken place.

Figure 5 shows that resulting future settlements will be far from being uniform, and as structures built on these grounds accumulate differential settlements, irreversible structural damage will gradually accumulate. Differential settlements induce tilts and distortions which may lead to the appearance of tension zones in masonries that will eventually produce fissures and cracks. This, in turn, increases structural vulnerability to other detrimental 


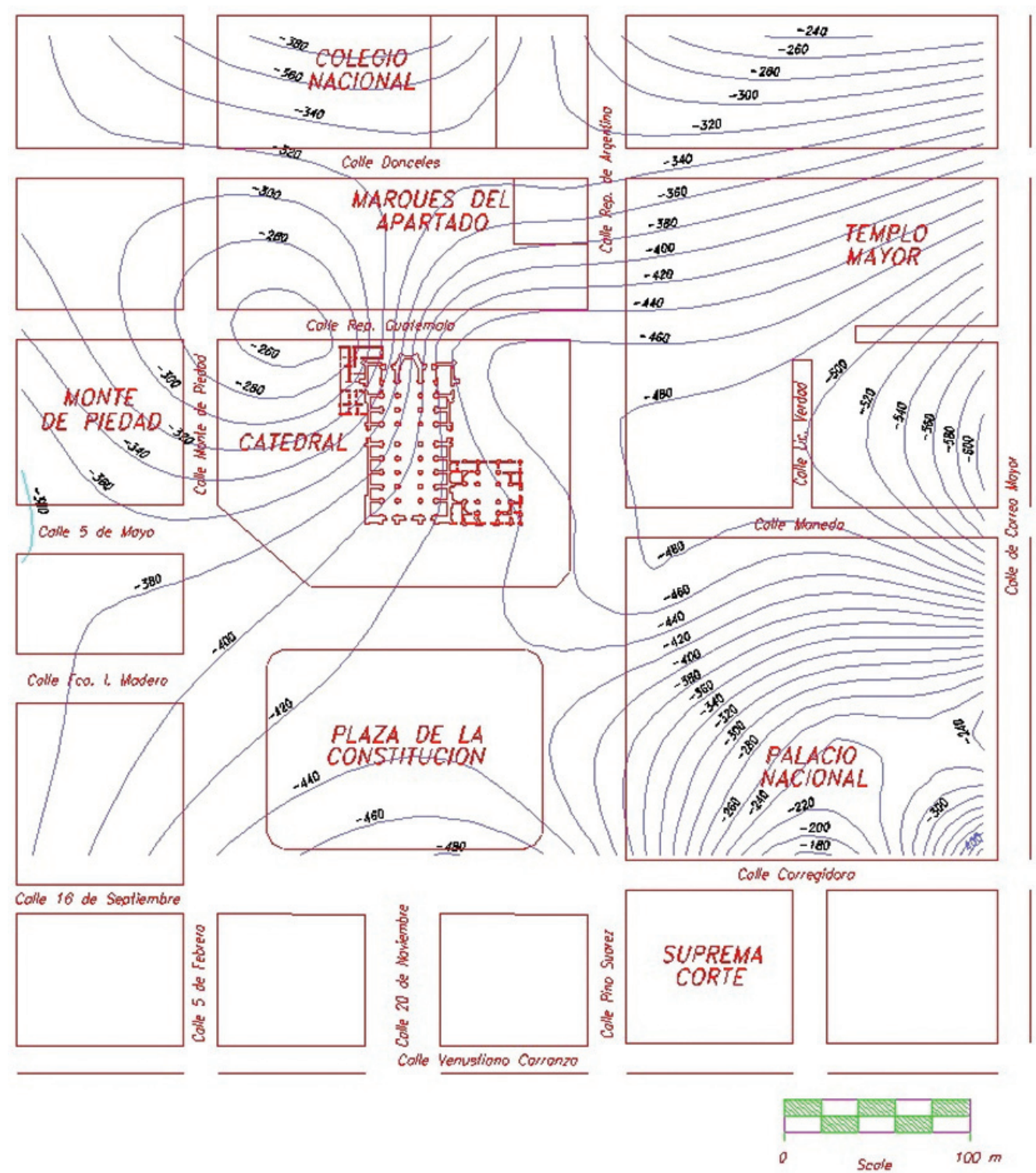

Figure 5. Settlement contour lines, in cm, estimated for the year 2075.

agents including reduction of their capacity to tolerate further differential settlements. In earthquake-prone regions however, differential settlements increase substantially the seismic vulnerability of structures.

\section{Time varying response in central Mexico City}

In looking at the effects of earthquakes in old structures such as those of Mexico City's architectural heritage, one must first look at the detrimental effects of differential settlements. The characteristics and intensity of future seismic events must be considered. The characteristics of the source and local site conditions are key factors in the distribution of damage.

\subsection{Seismicity in Mexico}

Seismicity in Mexico is determined by earthquakes that occur in a complex structural context, as illustrated in Figure 6 (Seyfried et al., 1991):

- Local earthquakes: These originate within the basin that contained the old lake system or close to it. Several medium or low intensity local earthquakes were recorded during the $20^{\text {th }}$ century.

- Earthquakes originating in the North American Plate: The Great Acambay Earthquake of 1912 originated in a graben some $70 \mathrm{~km}$ northwest of the city. The graben still threatens the city and seismologists still ponder whether a similar event may actually occur in the near future.

- Subduction earthquakes off the Mexican Pacific Coast: 


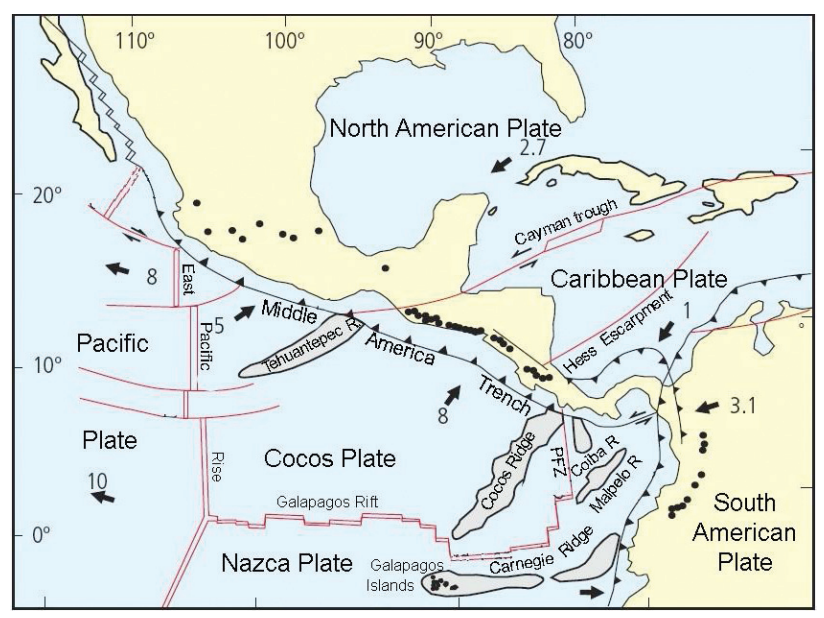

Figure 6. Structural context of earthquakes in the Mexico area.

These originate by the subduction of the Cocos Plate under the North American Plate. By far, these are the events that have caused the greatest damage in the city. The Guerrero earthquakes of 1909, 1957 and 1979 originated there as well as Great Michoacán Earthquakes of 1911 and 1985. Subduction earthquakes are the most frequent and are generally the most damaging.

- Earthquakes in the subducted Cocos Plate: These are normal faulting events that originate at intermediate depths of 50 to $100 \mathrm{~km}$. They have produced damage in inland states east of the city and cannot be overlooked in the assessment of seismic risks in Mexico City, but they can be considered as normal faulting events with return periods of a few decades.

\subsection{Historical background}

As cited in Cerca et al. (2005), the Aztecs and other pre-Hispanic peoples in the Basin of Mexico recorded earthquakes, and few descriptions of the damage they caused have reached modern historians, but it is not possible to assess seismic intensities or degree of damage from these descriptions. Archaeological data have shown that the pyramids in Tenochtitlan, built from manually compacted clay reinforced with masonry walls forming cells, suffered local slope failures probably enhanced by differential settlements (Tamez et al., 1997). It can be speculated that some of these local failures may have occurred during earthquakes. On the other hand, it is the authors' opinion that the probability of having a massive earthquake induced slope failure is very small indeed, given the presence of the reinforcing masonry walls within the core of the pyramids. The houses and palaces for the Aztec royalty were rigid low rise masonry structures which were also exposed to differential settlements, making them more vulnerable to suffer damage during earthquakes on account of their heavy ceilings.

European masons soon learned that in Mexico City heavy and slender structures could not sustain seismic forces especially if they had tilted or were inclined. Cervantes de Salazar provides the first rule for constructing seismic resistant structures in the Americas, which consisted simply in limiting their height to two stories. Of course, churches, especially their towers and spires, did not comply with this rule. Historians have recorded many accounts of fallen, tilted or collapsed church towers during earthquakes (GarcíaAcosta and Suárez-Reynoso, 1996). Tilts and distortion brought about by differential settlements, for example, prepared the central dome at the church of Santa Teresa la Antigua for its collapse in the great 1845 earthquake during which the bell tower at San Lorenzo tilted and cracked diagonally.

Still, objective observers that visited the country in the early $19^{\text {th }}$ century considered that earthquake damage in Mexico City was small, compared to damage and destruction sustained in other cities (Humboldt, 1822; Ward, 1828). Indeed, most damage concentrated in water and sewage pipes and in aqueducts. Disasters in the city really began during the $20^{\text {th }}$ century when newer more vulnerable structures were built. In the central part of the city, where resonant site periods range between 1 to $3 \mathrm{~s}$, approximately, the older more rigid structures, having short natural periods (say, 0.3 to $0.5 \mathrm{~s}$ ), fared better than some of the newer more flexible constructions with longer natural periods (more than $1 \mathrm{~s})$. Note that as structures accumulate damage, their natural periods become longer and may even become dangerously close to the site natural period, especially in the transition zones along the edges of the old lakes.

An example of how the older colonial buildings behave during an earthquake is provided by looking at records obtained from a network of seven accelerometers which were installed in the Metropolitan Cathedral in late 1996. These strong motion instruments have been triggered several times, and information gathered during these events confirmed that seismic motions in the Cathedral's structure are influenced by a very strong interaction effect with its foundation and the underlying clay strata. An illustrative example of the soil-structure interaction effects is provided in Figure 7 which shows three elastic response spectra (5\% damping) obtained from accelerograms recorded at a site in the western atrium (free field station), at the basement (crypt level) and at the main dome on January $11^{\text {th }} 1997$, during a 7.3 magnitude earthquake, whose epicenter was located some $600 \mathrm{~km}$ west of Mexico City. Low period peaks (less than $1 \mathrm{~s}$ ), which are present in the free field spectrum, are attenuated in the spectrum calculated at the basement; spectral ordinates show peaks near $1.5 \mathrm{~s}$ and these can be associated with the response of the soil deposits. Spectral peaks at around $2.5 \mathrm{~s}$ are due to rocking motions in the transept, mainly in the N-S direction. Amplification of spectral ordinates is not significant and this suggests that the transept moved essentially as a rigid body during 


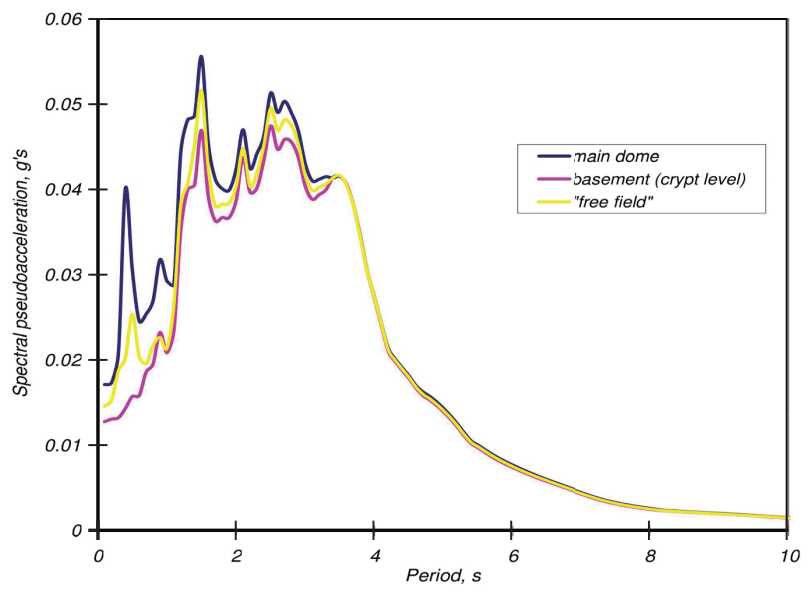

Figure 7. Elastic response spectra from strong motions recorded at the Metropolitan Cathedral on 11 January 1977.

this earthquake. Also note that spectral ordinates are rather small; maximum acceleration at the free field station was only 15 gals. From the analysis of motions recorded on the rooftop near the apse and near the western tower, it was concluded that motions in these two zones of the Cathedral and in its transept are independent. This is explained by the existence of families of fissures separating them.

Overall, the seismic response of the Cathedral has been acceptable, but the situation could change if additional differential settlements were to accumulate in the future, and this was indeed a major issue when deciding to underexcavate the cathedral (Meli and Sánchez, 1995). Similar conclusions may be reached when analyzing other colonial structures in the city.

\subsection{Effects on dynamic properties}

Local soil conditions, i.e. local site effects, have a major influence on seismic intensity distribution in the former lake area in Mexico City. In this city, a distinctive feature is the extremely large amplification of seismic motions associated with periods that coincide with the soft clay deposits' natural periods. Material properties which determine the dynamic behavior of soil deposits such as density, shear modulus and internal damping, being as they are, effective-stressdependent, are all affected by regional consolidation induced by deep well pumping. Changes on dynamic soil properties brought about by pumping-induced regional consolidation have been widely documented from the results of laboratory and field tests (Ovando-Shelley et al., 2007).

The dependency of shear wave velocity on effective stress increments can be stated explicitly from the following expression for the shear modulus at small strains, $G_{\max }$, which was derived from the results of resonant column and cyclic triaxial tests performed on clay samples retrieved from several sites in the former lake bed, in Mexico City (Romo, 1995; Romo and Ovando, 1996):
$G_{\max }=\rho V_{s}^{2}=122 p_{a}\left(\frac{1}{P I-I_{r}}\right)^{\left(P I-I_{r}\right)}\left(\frac{p_{0}^{\prime}+\Delta u(t)}{p_{a}}\right)^{0.82}$

where $\rho$ is mass density; $V_{s}$ is shear wave velocity; $p_{0}$ is the in situ mean effective stress; $p_{a}$ is the atmospheric pressure; $P I$ is the plasticity index and $I_{r}$ is relative consistency. Hence:

$$
V_{s} \approx 11 \sqrt{\frac{p_{a}}{\rho}}\left(\frac{1}{P I-I_{r}}\right)^{\left(\frac{P I-I_{r}}{2}\right)}\left(\frac{p_{0}^{\prime}+\Delta u(t)}{p_{a}}\right)^{0.41}
$$

$\Delta u(t)$ is a pore pressure depletion function obtained from equations 1 to 3 , for example. Index properties, plasticity index and relative consistency, have been included in expressions 4 and 5, as noted before by other authors (Dobry and Vucetic, 1997).

The complete shear modulus-strain relationship for the Mexico City clays can be formulated by means of hyperbolic functions of the type (Gonzalez, 2005):

$$
G=G_{\max }[1-H(\gamma)]
$$

where $H(\gamma)$ is:

$$
H(\gamma)=\left[\frac{\left(\gamma / \gamma_{r}\right)^{2 B}}{1+\left(\gamma / \gamma_{r}\right)^{2 B}}\right]^{A}
$$

and $\gamma$ is the shear strain; $A$ and $B$ are experimentally determined parameters that also depend on soil plasticity whereas $\gamma_{r}$ is a reference strain (Romo, 1995). Damping ratios can also be expressed by means of the same hyperbolic function:

$$
\lambda=\left(\lambda_{\max }-\lambda_{\min }\right) H(\gamma)+\lambda_{\min }
$$

where $\lambda_{\max }$ and $\lambda_{\text {min }}$ are the maximum and minimum values of damping ratio, experimentally determined over a convenient range of shear strains.

Effective stress increments brought about by water pumping from the aquifers will also modify (shorten) the resonant dominant periods of the soft clay deposits undergoing regional consolidation:

$$
T_{0}(t)=\frac{4[h-\delta(t)]}{\sqrt{G_{\text {avg }} / \rho_{\text {avg }}}}=\frac{4[h-\delta(t)]}{V_{\text {savg }}(t)}
$$

where $h$ is the total thickness of the compressible strata and $\delta(t)$ is the total vertical deformation at time $t$. Subindixes refer to average values of shear modulus, mass density and shear wave propagation velocity. Average shear wave velocity is:

$$
V_{\text {savg }}(t)=\sum \frac{V_{\text {si }}(t)\left(h_{i}-\delta_{i}(t)\right)}{h-\delta(t)}
$$


where $h_{i}$ is the initial thickness of stratum $i$ that undergoes a deformation given by $\delta_{i}(t)$; the shear wave velocity of that stratum at time $t$ is $V_{s i}(t)$.

As seen in expressions 9 and 10 , the shortening of periods is due to the compression of the clay strata and to the increase of stiffness or shear wave velocity.

\subsection{Seismic response}

Seismic response analyses were made using a one dimensional wave propagation model in which the input motion consists of vertically propagating waves. Such simple models have been used previously to successfully predict the seismic response of Mexico City clay deposits in the largest part of the old lake zone (Rosenblueth and Ovando, 1991). The model used here solves the equations of motion using Haskell-Thomson's solution for a stratified medium (Haskell, 1953; Thomson, 1950), and obtains the response of the soil column using random vibration theory. Soil strata are assumed to be viscous-elastic materials characterized by frequency independent, non-linear, stiffness-strain and damping-strain curves such as the ones provided by equations 1 to 3 . Material non-linearities are introduced with the linear equivalent method. The theoretical bases of the program are explained elsewhere (Bárcena and Romo, 1994).

Average initial values of the relevant properties for analyzing the seismic response of the Metropolitan Cathedral site in central Mexico City were taken from a high quality geotechnical sounding reported by Tamez et al. (1997). Static and dynamic soil parameters needed for the analysis were updated from effective stress increments obtained from the integration of equations 1 to 3 , at different dates in the future; thicknesses of the strata were also adjusted. Input motions at the base of the model were defined from response spectra obtained from accelerograms recorded at a basalt outcrop in the south of the city i.e. assuming that the strata underlying the soils below $51 \mathrm{~m}$ are rigid.

The evolution of the site's seismic response is examined using input motions from the great Michoacán Earthquake of September $19^{\text {th }}, 1985$ which originated along the subduction zone off the Mexican Pacific coast, $300 \mathrm{~km}$ from the city $\left(\mathrm{M}_{\mathrm{c}}\right.$ $=8.1)$ and from the one of June $15^{\text {th }}, 1999$, with an epicenter located $186 \mathrm{~km}$ southeast of the city $\left(\mathrm{M}_{\mathrm{c}}=7.1\right)$. Motions produced by subduction quakes in the city are generally rich in low frequency components which are amplified by the soft clay deposits. Normal faulting events, like the Tehuacán Earthquake, generate motions which are richer in higher frequency components.

Response spectra obtained when the site was excited by motions recorded during the Great Michoacán Earthquake of 1985 show that the site's dominant period can be reduced substantially in the future (Figure 8). If the dominant period shortens due to the stiffening of the clays as they become more consolidated, maximum spectral amplitudes would increase steadily. With the soil properties obtained in 2000, the maximum spectral acceleration turned out to be about $0.65 \mathrm{~g}$, whereas the value estimated for the year 2100 reached $1.15 \mathrm{~g}$. On the other hand, maximum ground acceleration can also increase substantially: from $0.14 \mathrm{~g}$ for the year 2000 to 0.3 in the year 2100 .

Nevertheless, spectral amplification - i.e. the quotient between spectral ordinates and maximum ground acceleration - would vary over a relatively narrow range at the site's natural period: between 4.0 and 4.8 , as seen in Figure 9. Interestingly, spectral ordinates associated with the site's second mode displayed a relatively small amplitude, over the 100 years studied here. Furthermore, spectral amplification below $0.4 \mathrm{~s}$ is not significant. Another remarkable feature is that, even for the very large spectral ordinates obtained in the later future, the materials' behavior would remain mainly within the linear range.

The site's future spectral response to the Tehuacán Earthquake also shows the effect of the sharp reduction in its natural period. Accordingly, spectral ordinates at that period increased steadily from 2000 to 2040; between the latter year and 2060, they remain basically constant and increase noticeably again in 2100 (Figure 10). On the other hand, spectral ordinates associated with the site's second

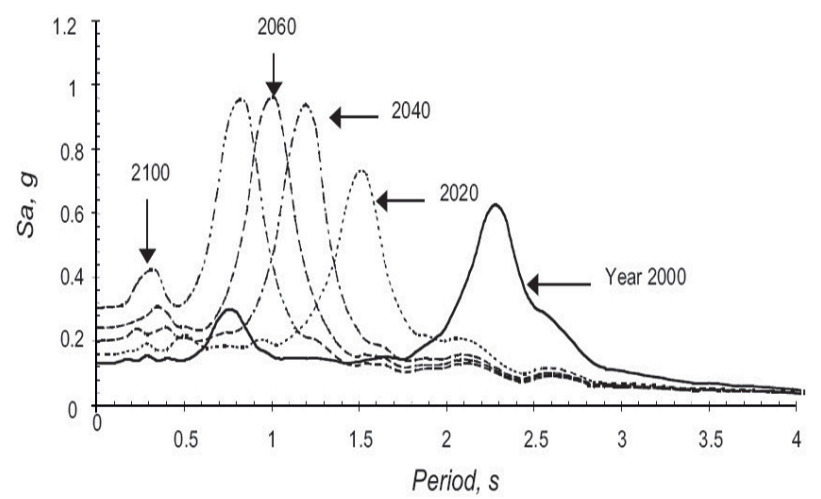

Figure 8. Response spectra at the Cathedral site using time-varying shear moduli. Input motion obtained from records logged at a basalt outcrop during the Great Michoacán Earthquake of 1985.

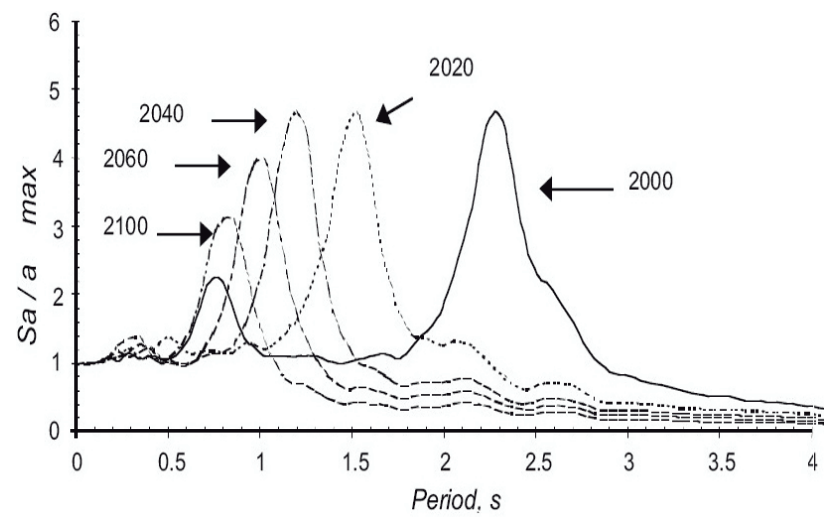

Figure 9. Spectral amplification obtained from the response spectra shown in the previous figure. 
mode are rather more significant than for the 1985 event. Maximum ground accelerations could vary from $0.014 \mathrm{~g}$ in the year 2000 to $0.05 \mathrm{~g}$ in 2100 , and spectral ordinates at the first mode from $0.036 \mathrm{~g}$ to $0.128 \mathrm{~g}$ in these same years, respectively. Spectral amplifications at the site's natural period could change from 2.2 to 3.2 , and from 2.1 to 2.4 at the second mode (Figure 11). Nonlinear effects would also be negligible as could have been expected a priori, given that the motions in the Tehuacán event were considerably less intense than for the Michoacán Earthquake.

\section{Conclusions}

The combined effects of regional subsidence and earthquakes pose serious threats to architectural monuments in Mexico City. Differential settlements brought about by regional consolidation induced by deep well pumping to extract water from the aquifers underlying the former lake bed in the city have increased the vulnerability of those

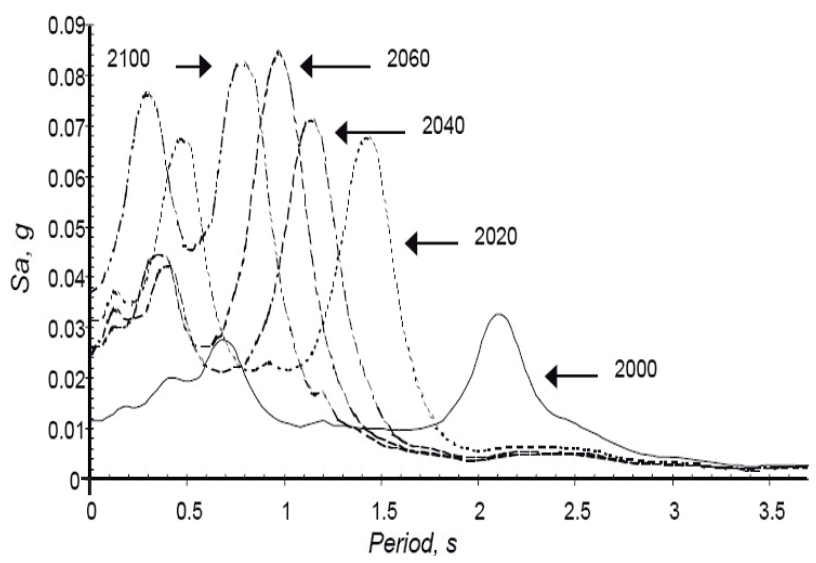

Figure 10. Response spectra at the Cathedral site using time-varying shear moduli. Input motion obtained from records logged at a basalt outcrop during the 1999 Tehuacán event.

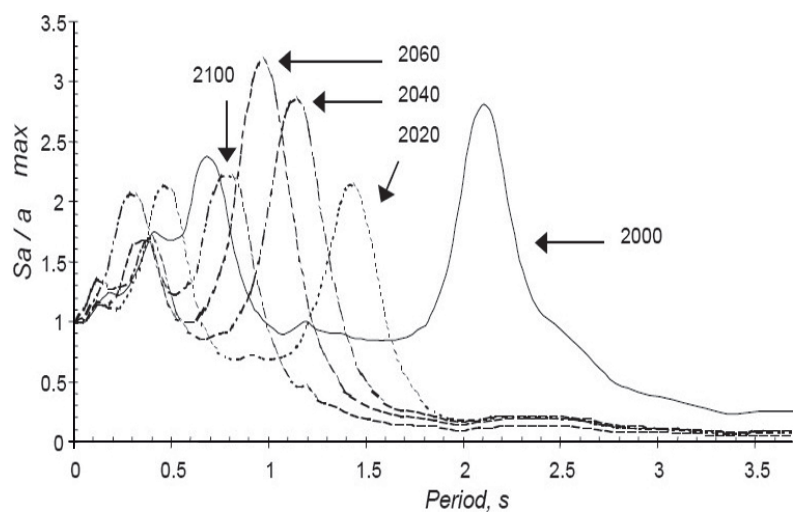

Figure 11. Spectral amplification obtained from the spectra shown in the previous figure. structures on account of the damage associated with them: cracks, fissures, tilts, structural distortions and the like.

Regional subsidence increases effective stresses within the soft clay masses. As the consolidation of the clays advances, their static and dynamic properties will change in the future.

Expected effective stress increments induced by the exploitation of the aquifers were estimated with a viscoplastic consolidation model which overcomes some of the limitations of Terzaghi's consolidation theory. Future expected settlements calculated with this model show that monuments in the central part of the city will undergo extremely large differential settlements in the years to come, which will in turn produce damage that will add to presently existing damage.

Dynamic soil properties and, consequently, dynamic response in the city will evolve. The future seismic response at a site near the Metropolitan Cathedral was examined studying its response to two earthquakes having different source mechanisms: the September $19^{\text {th }}, 1985$ earthquake, a subduction event, rich in long period components and the June $15^{\text {th }}$, 1999, Tehuacán Earthquake where short period components were important. Other seismogenic regions produce earthquakes that also affect Mexico City, but the two considered here represent extreme examples of the motions. The seismic response analyses presented and discussed here are certainly limited in their scope and aims but can't be considered by any means exceptional. Several general conclusions regarding the future of listed buildings in central Mexico City can be drawn from these results, pending further research into this matter:

Depletion of pore pressures within the clayey soils in Mexico City produces changes in their dynamic properties that can not be ignored.

Stiffening of the clays modifies (shortens) the dominant period of the soil deposits. Damage related to the appearance of differential settlements will, on the other hand, lengthen the natural period of old monumental buildings in the city. This combination of effects is potentially very dangerous to these structures.

Overall shortening of dominant periods will change the zones in which seismic movements are more intense in the city.

In the case of subduction earthquakes, the most hazardous zones will slowly migrate towards the centre of the old lake bed in the thicker clay strata.

The transition zone, located near the edges of the lake, where more rigid clay deposits exist, will become more vulnerable to high frequency events, i.e. deep normal faulting earthquakes or those produced by neighboring active faults. The seismic vulnerability of damaged old structures may increase considerably in these areas.

Monuments located in certain parts of central Mexico City, subjected to high, long standing external loads and to the effects of regional subsidence, like the site studied here, will also become more vulnerable to high frequency events. 
From the above, it is likely that many of those structures will not survive unless decisive actions are taken in order to increase their capacity to sustain further differential settlements in the future and reduce future increments in seismic vulnerability. The authors have identified nearly 30 structures that require urgent interventions but there are many others that may need to be intervened in the near future.

\section{References}

Bárcena, A., Romo, M.P., 1994, RADSH: programa de computadora para analizar depósitos de suelo estratificados horizontalmente sujetos a excitaciones dinámicas aleatorias, Internal Report: México, D.F., México, Instituto de Ingeniería, Universidad Nacional Autónoma de México, $54 \mathrm{p}$.

Carrillo, N., 1948, Influence of Artesian Wells in the Sinking of Mexico City, in Proceedings of the Second International Conference on Soil Mechanics and Foundation Engineering: Rotterdam, The Netherlands, International Society for Soil Mechanics and Foundation Engineering, 156-159.

Cerca, M., Carreón-Freyre, D., López-Quiroz, P., Ovando-Shelley, E., Doin, M.P., Gutiérrez-Calderón, R., Gonzalez-Hernández, M., Jimenez-Sánchez, A., Blancas-Domínguez, D., 2012, Engineering geology approach to the effects of land subsidence in Mexico City, in Aranda-Gómez JJ, Tolson, G., Molina-Garza, R.S. (eds.), The Southern Cordillera and Beyond: GSA Field Guide 25, p. 115-134.

Cervantes de Salazar, F., 1978, La vida en México en 1554, 1555: México, D.F., México, Editorial Porrúa, 233 p.

Dobry, R.,Vucetic M., 1997, Dynamic properties and seismic response of soft clay deposits, in Mendoza M.J. (ed.), Simposio internacional de ingeniería geotécnica de suelos blandos: México, D.F., México, Sociedad Mexicana de Mecánica de Suelos, 2, 49-85.

García-Acosta, V., Suárez Reynoso, G., 1996, Los sismos en la historia de México: México, D.F., México, Fondo de Cultura Económica, $1,718 \mathrm{p}$.

González B.M., 2005, Modelación de las Propiedades Dinámicas de Arcillas Marinas: México, D.F., México, Universidad Nacional Autónoma de México, tesis de maestría, 109 p.

Haskell, N.H, 1953, The dispersion of surface waves in multilayered media: Bulletin of the Seismological Society of America, 43, 17-34.

Humboldt, A, 1978 (1822), Ensayo político sobre el reino de la Nueva España (1822): México, D.F., México, Editorial Porrúa, 696 p.

Marsal, R.J., Mazari, M., 1959, The Subsoil of Mexico City: México, D.F., México, Escuela de Ingeniería, Universidad Nacional Autónoma de México, 377 p.

Mazari M., 1996, La isla de los perros: México, D.F., México, El Colegio Nacional, $80 \mathrm{p}$.

Meli, R., Sánchez, R., 1995, Catedral Metropolitana: corrección geométrica, informe técnico, diagnóstico estructural: Mexico, Asociación de Amigos de la Catedral Metropolitana de México A.C., 141-188.

Musset, A., 1992, El Agua en el Valle de México: siglos XVI-XVIII, México, D.F., México, Editorial Pórtico, 245 pp.
Ovando, S.E., Ossa L.A., 2004, Modelo elastoviscoplástico para la consolidación de los suelos y su aplicación al hundimiento regional de la ciudad de México, in Memorias de la XXII Reunión Nacional de Mecánica de Suelos: Guadalajara, México, Sociedad Mexicana de Mecánica de Suelos, 1, 291-299.

Ovando-Shelley, E., Romo M.P., Contreras, N., Giralt, A., 2003, Some Implications of the Future Evolution of Central Mexico City's Subsoil Properties due to Water Pumping: Geofísica Internacional, 42, 185-204.

Ovando-Shelley, E., Romo, M.P., Ossa, A., 2007, The sinking of Mexico city: Its effects on soil properties and seismic response: Soil Dynamics and Earthquake Engineering, 27, 333-343.

Romo M.P., 1995, Clay behaviour, ground response and soil-structure interaction studies in Mexico City, State of the Art Paper, in Prakash, S. (ed.), Proc. Third International Conference on Recent Advances in Geotechnical Engineering and Soil Dynamics: Rolla, Saint Louis, Missouri, U.S.A., University of Missouri.

Romo M.P., Ovando E., 1996, Modelling the dynamic behaviour of Mexican clays, in Proc. XI International Conference on Earthquake Engineering, Acapulco, México, Elsevier Science, http://www.iitk. ac.in/nicee/wcee/article/11_1028.PDF

Rosenblueth, E.,Ovando, E., 1991, Geotechnical lessons learned from Mexico and other recent earthquakes", in Second International Conference on Recent Advances in Geotechnical Engineering and Soil Dynamics: Saint Louis, Missouri, U.S.A., II, 1799-1819.

Santoyo-Villa E., Ovando-Shelley, E., Mooser, F., León, E., 2005, Síntesis Geotécnica de la Cuenca del Valle de México: México, D.F., México, TGC Ediciones, $171 \mathrm{p}$.

Seyfried, H., Astorga, A., Amann, H., Calvo, C., Kolb, W., Schmidt, H., Winsemann, J., 1991, Anatomy of an evolving island: tectonic and eustatic control in the south Central American fore-arc area. Sedimentation, Tectonics and Eustasy. Sea-level Changes at Active Margins", in MacDonald D. (ed.), Special Publication Number 12, International Association of Sedimentologists, Blackwell Scientific Publications, London, United Kingdom, 217-240.

Tamez, E., 1992, Hundimientos diferenciales de edificios coloniales en el Centro Histórico de la Ciudad de México, in Undécima Conferencia Nabor Carrillo: Zacatecas, México, Sociedad Mexicana de Mecánica de Suelos, $94 \mathrm{p}$.

Tamez, E., Ovando-Shelley, E., Santoyo, E., 1997, Underexcavation of Mexico City's Metropolitan Cathedral and Sagrario Church, Special Invited Lecture, in Proc., XIV ${ }^{\text {th }}$ International Conference on Soil Mechanics and Foundation Engineering: Hamburg, Germany, 4, 2105-2126.

Thomson, W.T., 1950, Transmission of elastic waves through a stratified soil: Journal of Applied Physics, 21, 89-93.

Ward, H.G., 1828, México en 1827: México, D.F., México, Fondo de Cultura Económica, 73, 203 p.

Yin, J.H., Graham J., 1994, Equivalent times and one dimensional elastic viscoplastic modeling of time dependent stress-strain behavior of clays: Canadian Geotechnical Journal, 31, 42-52.

Yin, J.H., Graham J., 1996, Elastic visco-plastic modeling of one dimensional consolidation: Geotechnique, 46, 515-527.

Manuscript received: January 5, 2011.

Corrected manuscript received: August 25, 2011.

Manuscript accepted: October 19, 2011. 